\begin{tabular}{|l|l}
\hline & JTMT \\
Jurnal Tadris Matematika \\
Vol 1 No 2 2020 \\
ISSN (print) : $2745-956 \mathrm{X}$ \\
ISSN (online) : $2745-9551$ \\
Homepage $: \underline{\text { http://journal.iaimsinjai.ac.id/index.php/Jtm }}$ \\
\hline
\end{tabular}

\title{
KEPRAKTISAN PEMBELAJARAN MENGGUNAKNAN APLIKASI EDMODO
}

\author{
Prima Mytra $^{1}$, Meisaraswaty Arsyad ${ }^{2}$, Anggy Heriyanti ${ }^{3}$ \\ ${ }^{1}$ Institut Agama Islam Muhammadiyah Sinjai \\ ${ }^{2}$ Institut Agama Islam Muhammadiyah Sinjai \\ ${ }^{3}$ Institut Agama Islam Muhammadiyah Sinjai \\ E-mail: mytraprima@gmail.com, Tlp:+6285239211417
}

\begin{abstract}
Abstrak
Berbagai macam media pembelajaran online saat ini bermunculan, salah satunya edmodo. Edmodo merupakan media pembelajaran dalam bentuk website dengan konsep media social sebagai ruang belajar virtual bagi siswa. Tujuan artikel ini adalah memperkenalkan edmodo sebagai salah satu media pembelajaran online yang menawarkan model dan strategi belajar yang akan memudahkan guru, dosen, dan orang tua mengotrol mahasiswa sehingga dapat belajar dengan baik serta dapat meningkatkan minat belajar mahasiswa. Metode penelitian yang digunakan adalah kualitatif deskriptif. Hasil dari angket dan wawancara dari subjek penlitian menunjukkan bahwa belajar jarak jauh menjadi lebih praktis dengan menggunakan media edmodo.
\end{abstract}

Kata Kunci: Edmodo, e-learning, belajar

\begin{abstract}
Various kinds of online learning media are currently emerging, one of which is edmodo. Edmodo is a learning media in the form of a website with the concept of social media as a virtual learning space for students. The purpose of this article is to introduce Edmodo as an online learning medium that offers learning models and strategies that will make it easier for teachers, lecturers, and parents to control students so that they can learn well and can increase student interest in learning. The research method used is descriptive qualitative. The results of questionnaires and interviews from research subjects show that distance learning becomes more practical using edmodo media.
\end{abstract}

Keywords: Edmodo, e-learning, learning

\section{Pendahuluan}

Perkembangan teknologi sudah banyak memberi pengaruh terhadap cara hidup kita, salah satunya adalah dalam bidang pendidikan dengan penggunaan e-learning dalam kegiatan pembelajaran di sekolah maupun perguruan tinggi. E-learning dapat digunakan sebagai alternatif atas permasalahan dalam bidang pendidikan, baik sebagai tambahan, pelengkap maupun pengganti atas kegiatan pembelajaran yang sudah ada. E- learning adalah Pembelajaran yang disusun dengan tujuan menggunakan sistem elektronik atau komputer sehingga mampu mendukung proses pembelajaran (Michael, 2013:27).

Salah satu aplikasi pada internet yang bisa digunakan untuk e-learning adalah Edmodo. Edmodo adalah sebuah platform pembelajaran sosial untuk guru/dosen, siswa/mahasiswa maupun untuk orang tua/wali yang dikembangkan pada akhir 2008 oleh Nic Borg dan Jeff O'Hara. Dengan media edmodo mahasiswa dapat dikontol secara berkelanjutan oleh orang tua dengan adanya akun kontrol yang terhubung kepada orang tua mahasiswa. 


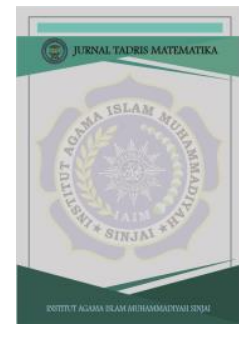

JTMT

Jurnal Tadris Matematika

Vol 1 No 22020

ISSN (print) : 2745-956X

ISSN (online) : 2745-9551

Homepage : http://journal.iaimsinjai.ac.id/index.php/Jtm

\section{Metode}

Jenis penelitian yang digunakan adalah penelitian kualitatif dengan mendeskripsikan hasil penelitian pengajaran yang telah diterapkan oleh peneliti dalam pembelajaran dan mendeskripsikan hasil pengalaman mahasiswa yang telah belajar dengan menggunakan media edmodo. Penelitian berlangsung pada saat perkuliahan dengan menggunakan edmodo sebagai media pembelajaran pada semester genap tahun ajaran 2018-2019 di IAI Muhammadiyah Sinjai.

\subsection{Lokasi Penelitian dan Sumber Data}

Penelitian ini dilaksanakan di kampus IAI Muhammadiyah Sinjai di Kabupaten Sinjai yang berlokasi di JL.Sultan Hasanuddin No. 20, Kabupaten Sinjai, Sulawesi Selatan. Sumber data dalam penelitian ini diperoleh dari instrument wawancara mahasiswa yang pernah belajar menggunakan edmodo dan rekam jejak penulis yang telah menerapkan sistem pembelajaran online menggunakan media edmodo dikalangan mahasiswa IAI Muhammadiyah Sinjai. Adapun instrument yang digunakan adalah instrument wawancara, instrument angket dan skala likert.

\section{Hasil dan Pembahasan}

Setelah melakukan perkuliahan secara online, pertemuan selanjutnya secara tatap muka, peneliti menayakan kepada mahasiswa bagaimana proses perkuliahan yang dirasakan oleh mahasiswa secara online. Setiap mahasiswa mengutarakan pengalaman mereka saat melakukan perkuliahan online dan mengatakan merasa senang mengikuti proses perkuliahan online. Dengan menunjukkan angka $90 \%$ mahasiswa merasa dimudahkan atau merasa praktis mengikuti proses perkuliahan secara online dengan alasan yang bermacam-macam. Ada yang mengatakan tidak perlu terburu-buru ke kampus, cukup online di kamar saja, sambil makan dan minum di warkop, dsb.

Angket yang dibagikan merupakan instrument angket skala likert yang telah dikualifikasikan menjadi tiga bagian yaitu tidak praktis, praktis, sangat praktis. Data hasil angket disajikan sebagai berikut:

Tabel 1. Kualifikasi Angket

\begin{tabular}{lc}
\hline \multicolumn{1}{c}{ Data Statistik } & Skor Statistik \\
\hline Tidak Praktis & $10 \%$ \\
Praktis & $10 \%$ \\
Sangat Praktis & $80 \%$ \\
\hline
\end{tabular}

Dari 90 orang populasi mahasiswa menunjukkan bahwa $90 \%$ mengatakan proses perkuliahan menggunakan edmodo sangat memudahkan dalam mengikuti proses perkuliahan. Hanya 9 diantara 90 orang mengatakan tidak praktis. Kemudian peneliti mengambil langkah wawancara dengan memilih 1 subjek dari ketiga kualifikasi yang tersedia. Pengambilan subjek dilakukan secara acak.

Hasil penelitian menunjukkan hasil yang positif bahwa pembelajaran online menggunakan edmodo dapat memudahkan dalam perkuliahan dan membuat pembelajaran menjadi lebih praktis dengan memanfaatkan internet yang telah menajdi salah satu kebutuhan primer semua kalangan saat ini apalagi dikalangan kampus sebagai media pendidikan untuk meningkatkan mutu generasi muda agar dapat bersaing diera sistem teknologi sudah memasuki teknologi industri 4.0 yang canggih dan mewabah dikalangan masyarakat saat ini.

\section{Simpulan}

Belajar menggunakan media edmodo membuat pembelajaan menjadi lebih praktis dan meningkatkan minat belajar mahasiswa dilingkup Institut Agama Islam Muhammadiyah Sinjai. Dengan penelitian ini, memberikan informasi kepada guru, dosen, dan pengajar bahwa dapat menerapkan pembelajaran online dengan media edmodo dalam kegiatan belajar mengajar. 


\section{Daftar Pustaka}

Holland, Catherine, and Lin Muilenburg. "Supporting student collaboration: Edmodo in the classroom." Society for Information Technology \& Teacher Education International Conference. Association for the Advancement of Computing in Education (AACE), 2011.

Nugroho, Mahendra Adhi dkk.Pembuatan Media Pembelajaran Berbasis Web Blog Dan Aplikasi Android Bagi Guru SMK. UNYYogyakarta, 2016.

Raharjo, Jajo Firman, and Herri Sulaiman. "Mengembangkan Kemampuan Pemahaman Konsep Matematika Diskrit Dan Pembentukan Karakter Konstruktivis Mahasiswa Melalui Pengembangan Bahan Ajar Berbantuan Aplikasi Education Edmodo Bermodelkan Progresif Pace (Project, Activity, Cooperative and Exercise)." Teorema: Teori dan Riset Matematika 2.1 (2017): 47-62.

Sihes, Ahmad Johari. "Konsep Pembelajaran." Diunduh dari: http://eprints. utm. my/id/eprint/id/file/180566 (2011).

Tambunan, Hamonangan. Pengembangan Pembelajaran Berbasis Website Dalam Matakuliah Pengaturan Mesin Listrik. Jurnal Cakrawala Pendidikan 2013. Vol. 32 No.1.

Taufik, Muhammad dkk.Pelatihan Media Pembelajaran Berbasis Web Kepada Guru IPA SMP Kota Mataram.Jurnal Pendidikan dan Pengabdian Masyarakat 2018 Vol. 1 No. 1. 